\title{
FAMILY BUSINESS BACKGROUND AND ENTREPRENEURSHIP FRIENDLY ENVIRONMENT AT UNIVERSITY ON STUDENTS INTENTION TO START-UP NEW BUSINESS
}

Irwansyah Irwansyah $^{1}$, Ardi Paminto ${ }^{2}$, Yana Ulfah ${ }^{3}$, Muhammad Ikbal ${ }^{4}$, Dio Caisar Darma ${ }^{5 *}$

${ }^{4}$ Lecturer, Departement of Accounting, Faculty of Economics and Business, Mulawarman University, Samarinda, 75117, Indonesia; ${ }^{2}$ Senior Lecturer, Departement of Management, Faculty of Economics and Business, Mulawarman University, Samarinda, 75117, Indonesia; ${ }^{1,3}$ Senior Lecturer, Departement of Accounting, Faculty of Economics and Business, Mulawarman University, Samarinda, 75117, Indonesia; ${ }^{5 *}$ Researcher, Department of Management, Sekolah Tinggi Ilmu Ekonomi Samarinda, Samarinda, 75242, Indonesia.

Email: ${ }^{1}$ irwansyah@feb.unmul.ac.id, ${ }^{2}$ ardi.paminto@feb.unmul.ac.id, ${ }^{3}$ yana.ulfah@ feb.unmul.ac.id,

${ }^{4}$ muhammad.ikbal@feb.unmul.ac.id, ${ }^{5 *}$ diocaisar@stiesam.ac.id

Article History: Received on $18^{\text {th }}$ June 2020, Revised on $10^{\text {th }}$ March 2021, Published on $19^{\text {th }}$ March 2021

\section{Abstract}

Purpose of the study: Entrepreneurship is one of the drivers of the national economy, youth and students are the main driving force for forming young entrepreneurs. Our research aimed at examining the students' intention towards action becoming an entrepreneur which is moderated by several factors, namely the background of family business ownership and the entrepreneurial university environment.

Methodology: Data collection by using survey methods, with samples of students in several universities in Indonesia. From January 2020 to April 2020 there were 983 questionnaires sent by email, which apps or Instagram accounts owned by respondents. As many as 983 questionnaires were distributed, only 234 questionnaires returned, and 187 completed questionnaires and can be used.

Main Findings: The analysis results showed variable of perceived desirability positively and have a significant effect on the intention to be entrepreneurial, while perceived feasibility does not have a significant effect on the respondents' intention for entrepreneurship, then the entrepreneurial intention describes the actions taken to implement the intention become entrepreneurs in the future. In the third stage, generate negative moderating effects from a family business background and not significant, as well as the entrepreneurial university environment produces positive but not significant moderating effects.

Applications of this study: We used the planned behaviour theory an effort to test the intentions and desires of student entrepreneurship which are moderated by two factors.

Novelty/Originality of this study: This study presents problems regarding family business, entrepreneurship within the University, and students' intentions in starting a business. The study object, analysis model, and study results show differences from previous studies, so it is very interesting to be used as references in the future.

Keywords: Perceived Feasibility, Perceived Desirability, Entrepreneurial Intention, Family Business, Entrepreneurial University Environment, Entrepreneurial Activities.

\section{INTRODUCTION}

The Indonesian government has promoted the National Entrepreneurship Movement (GKN) which is a community movement built from the ground up and from the bottom, so this movement has been formed to have strong growth. It was among others that make Indonesian entrepreneurs ration which in 2013/2014 was 1.67\%, today according to BPSStatistics of Indonesia (2017) has increased to $3.1 \%$ in 2016 . The Indonesian government encourages youth, especially students interested in entrepreneurship, to take a credit facility like business credit for low-level society (KUR) that has 9\% interest, then Revolving Fund Management Institution (LPDB) with a very low-interest rate of 0.2 to $0.3 \%$ per month and other credit facilities. These various lightweight credit facilities are expected to be able to encourage the growth of young entrepreneurs who can provide multiplier effects for society in an effort to open new jobs.

The position of micro to medium enterprises (MSMEs) in the Indonesian economy can be described as a condition that is still weak, which can significantly hinder the rate of economic growth in the country. However, the contribution of these MSMEs to GDP formation has grown in the last five years. The Indonesian Ministry of Cooperatives and MSMEs noted that the role of MSMEs in encouraging National GDP in 2017 was around 57.84 in 2016, increasing to $60.34 \%$ in Indonesia's GDP portion. Another impact of SMEs is the opening of business opportunities and the absorption of domestic workers. Absorption of labor in the MSME sector experienced growth from $96.99 \%$ to $97.22 \%$ in the last five years from 2012 to 2017. Indonesian government efforts that continue to encourage MSMEs through the entrepreneurial intention will encourage crisis prevention, unemployment, and poverty. The specific form of such effort would try to improve a career in entrepreneurship among youth in Indonesia and create favorable conditions and will encourage them to set up and run the company independently (Indriastuti et al., 2020; Muliadi et al., 2020; Wahyuningsih et al., 2020). 
Entrepreneurship is the main pillar of the nation's economy, especially for developing countries. Entrepreneurship supports national economic growth by becoming a pioneer in the development of technology and innovation, then encourages efficiency and creates new business opportunities and employment opportunities (Shane \& Venkataraman, 2000). One focus of the research questions that are often raised is what makes people want to become entrepreneurs? more specifically, what factors encourage someone to become an entrepreneur? This concept is commonly referred to as Students' Intention to be an entrepreneurial (Bird \& Jelinek, 1988; Piperopoulos \& Dimov, 2015; Fayolle \& Gailly, 2015; Saeed et al., 2015; Boyd \& Vozikis, 1994). Regarding the desire to become an entrepreneur, Bird \& Jelinek (1988) refers to the term intentionality which defines the condition of one's mind that guides the mind toward attention, life experience, and ultimately cause an action on a goal, so that it becomes an intentional behavior, or by Krueger (1993, 2019) referred to as behavior that had been planned before.

Youth especially students are very promising groups in this independent business aspect (Shchegolev et al., 2018). Entrepreneurship predicate in students can encourage the integration of young people into the business environment, become a successful young executive, and increase the economic activity of millennial (Abbasianchavari \& Moritz, 2020). As an educated, students have the knowledge as social capital in developing business models, however, even though entrepreneurship education acquired by students is considered important (Westhead \& Solesvik, 2016; Premand et al., 2016; Testa \& Frascheri, 2015; Ebewo et al., 2017), but few empirical studies have emerged, different from general education, about perceptions that link to students' intention entrepreneurship (Nowak, 2016; Popescu et al., 2016; Denanyoh et al., 2015). In the last 10 years, the youth desire to become entrepreneurs is quite strong, supported by easy access to information as it is today.

For example, a survey involving several students from 32 universities in Russia, predominantly stated their intention to start their own business within a period of time after graduation. However, these entrepreneurial aspirations are not always in line with the actual implementation of business ideas (Shirokova et al., 2015). The intention-action gap phenomenon, that is, fails to apply previous intentions (Ajzen et al., 2009; Armitage \& Conner, 2001; Orbell \& Sheeran, 1998). However, very few relevant studies have been conducted by researchers specifically in the entrepreneurial field (Shirokova et al., 2015; van Gelderen et al., 2015). Little or even no studies have been found in Indonesia. The use of variable education is quite a lot, but only a few special entrepreneurship education, especially at the level of higher education (Byabashaija \& Katono, 2011), so there are still many opportunities to examine entrepreneurship special education towards entrepreneurial intentions.

The intention and implementation of a person to have an independent business are very dependent on personal characteristics (Liñán \& Fayolle, 2015). On the other hand, external environmental factors play an important role in this, because they can influence individual behavior in their involvement in entrepreneurship (Rauch, 2014). This assumption is based on the concept of "sticky perspective" which highlights people's actions through social relations systems and the environmental context in which they live (Welter \& Xheneti, 2013; Welter \& Smallbone, 2011). The research aimed at examining the impact of influencing factors on the university students' context in Indonesia who move from doing business independently intention to take action to start a new business. The research authenticity is laying on the use of intentions and elaboration of planned behavior theory (Ajzen, 1991) by identifying the reasons for this success, which was inspired by the theory of entrepreneurial cognition, the researcher develops this reason to include perceived feasibility and perceived desirability in the combination of this research model, based on the concept in the theory of entrepreneurial cognition or entrepreneurial cognition theory, namely the existence of heuristic-based logic that is affected by past experiences, an individual can solve problems or achieve goals that do not yet have a standard formulation (Busenitz \& Lau, 1996; Busenitz \& Barney, 1997; Mitchell et al., 2002).

The first part of this paper presents the theoretical basis and derives hypotheses from various relevant theoretical and research perspectives. Furthermore, the methodology used will be presented, describing the results of data analysis, and discussion of the result. The last section formulates conclusions, showed the study limitations, and outlines some recommendations for future research related to entrepreneurial research.

\section{LITERATURE REVIEW}

Planned behavior theory was originally named theory of reasoned action (TRA), developed in 1967, then the theory continues to be revised and expanded by Icek Ajzen and Martin Fishbein. According to the theory of planned behavior, actions that are targeted by individuals will usually be initiated by intention, which is influenced by elements of attitude, control, and norms. The intended personal attitude towards relevant activities, while behavioral control is seen based on the individual's perception of how easy or difficult their plans will be. The subjective norm is determined by the opinions of others, which can encourage or hinder someone from implementing plans (시zen, 1991).

Ajzen (2005) suggests that attitudes towards this behavior are driven by the belief that there is an impact on these behaviors or commonly called "behavioral beliefs". Beliefs can be associated with subjective judgments of an individual on the reality he/she faces, his understanding of himself, others, and his surroundings. This premise can be formed by connecting behavior with benefits or losses that might be obtained by the person concerned if he/she does this behavior.

Intention serves as a liaison between the above factors, the bridge to carry out actions, and achieve the desired goals (Armitage \& Conner, 2001). The intention formation mechanism still becomes the focus of researchers' attention who 
specializes in entrepreneurship (Bird \& Jelinek, 1988; Heuer \& Liñan, 2013; Krueger, 2019). The relationship between entrepreneurial intentions and concrete steps taken empirically explains the provisions of the theory of planned behavior (Kautonen et al., 2013, 2015; Liñán \& Fayolle, 2015; van Gelderen et al., 2015). For self-employment at the student level, this correlation has been true for older age groups as they generally have experience (Shirokova et al., 2015). In a choice situation, a career forces those who want to become entrepreneurs to start doing something, while on the other hand students are still struggling with their studies and this is the foundation for their future business growth.

Research of entrepreneurship requires a theory of how to explain phenomena or explain the interrelationships between concepts, both those that explain the concepts of personality, business strategy, and microeconomic theory. Each of these concepts can contribute. The first, economic theory about entrepreneurship is how to see that entrepreneurship can contribute to the creation of new jobs and business opportunity (Drucker, 2014; Low \& MacMillan, 1988; Toma et al., 2014; Edoho, 2016; Rumelt, 2005), indeed this economic theory is useful in assisting in identifying entrepreneurship and its effects, but unable to answer micro questions how psychology is in managing a business, how to technically manage a business and various obstacles that might arise in business activities. Second, in the last 50 years, research models based on psychology, sociology, personality, and behavior (McClelland, 1965, 1987; Colton, 1981), have presented personality factors and behavioral factors as determinants in the formation of new businesses and contribute to the development of the spirit and entrepreneurial spirit, especially for beginner and youth entrepreneurship (Tipu \& Ryan, 2016; Rokhman \& Ahamed, 2015; Contreras et al., 2017; Baluku et al., 2016), but to form a standard model that psychological and personality factors as the main determinants of entrepreneurship formation are still weak, insignificant and have not been the perfectly consistent result.

Various results of organizational and strategic management research, attention for 20 to 30 years is more focused on improving business performance that is highly dependent on the performance of the businessman, commonly referred to as organizational performance-based research (Sandberg \& Hofer, 1987; McDougall, 1989; Kunkel, 1991; Shane \& Venkataraman, 2000). Until the beginning of 2002, when marketing patterns began to change or have undergone a transformation from the manual era to the digital era, changes in research began to appear, where the online-based performance began (see online performance-based research).

Entrepreneurship is not only seen as an effort to create new business ideas, but also illustrates how psychological effects can build business confidence through experience and education, and the need for precise strategies to develop it. Entrepreneurship can play a role as an art of developing teamwork, creating innovation, and meeting the needs of goods and services for the market (Mitchell et al., 2002). In this regard, the Theory of Entrepreneurial Cognition states that heuristic-based rational thoughts are affected by the belief of scientific thought, a specific and systematic method that fosters experience in human beings as basic capital in decision-making that has no formula (Busenitz \& Lau 1996; Busenitz \& Barney, 1997).

The influence of perceived desirability (as an intention to do something) and perceived feasibility (as a condition of whether or not a business plan is feasible) on the desire become entrepreneurs is built based on several previous studies from various researchers who concerned with entrepreneurial intentions (Krueger, 2019; Saeed et al., 2015; Zapkau et al., 2015; Henley et al., 2017; Karimi et al., 2016; Fuller et al., 2018). This research has shown that the perceived desirability and the perceived feasibility are significant driving factors for entrepreneurial intention.

The concept of perceived desirability and perceived feasibility according to Shapero \& Sokol (1982) is essentially an initial step to form an individual plan to start a new business, although they do not explicitly use the concept of intention. The view of Shapero \& Sokol (1982) is supported by Ajzen's (1991) planned behavior theory, which argues that attitudes toward action (which is proxied by the concept of perceived desires), subjective norms, and behavioral control (represented by the concept of feasibility perception) are influential factors on the intention to become entrepreneurial (EI), specifically associated with students. Besides, the TPB model has been repeatedly tested empirically (Krueger, 2019; Henley et al., 2017; Karimi et al., 2016), the results of this study provide insights with very clear and complete argumentation on the pattern of the relationship between Perceived desirability (as an attitude towards action) and perceived feasibility (as subjective norms and behavioral controls) towards the intention of managing and establishing own business.

The family business is derivative, both natural derivatives (genes), then parents coercion to continue the business, then derivatives in the form of examples and even derivatives of assets and capital. Business ownership by a family can greatly determine student career choices. This condition will encourage a person to follow his parents' career path and start a business independently (Slavtchev et al., 2012). Parents can be role models for students in continuing careers (Chlosta et al., 2012). People who come from families that own business tend to have higher quality human and social capital formed by the experience, skills, and knowledge needed to manage a business that is followed by their parents, by participating in family company management (Lentz \& Laband, 1990; Mueller, 2006). This condition becomes an absolute advantage of someone who wants to continue business independently (entrepreneurship).

Students who often feel more confident that initially, only entrepreneurial intentions become an action, in the end, it is possible to create new businesses (Shirokova et al., 2015). In addition to this encouragement, some pieces of evidence state that since childhood these children have been involved in their parent's various business activities, especially 
family-run services, trade, and industry. In addition to developing human resources, business owners can help their children to find and acquire resources necessary to realize the intentions.

Capital and assets are the driving factors in running an independent business. This has become quite dominant in the fields of trade and industry (especially in big cities). Thus, parent-owned businesses serve as a source of financial support for children in the future and provide them with access to social capital including suppliers, network partners, investors, and customers (Dunn \& Holtz-Eakin, 2000; Slavtchev et al., 2012). Non-monetary capital support like this becomes the next driving factor, which is dominantly attracting more individuals into business and will provide success evidence.

Since the early 2000s, several universities have declared themselves as universities that support entrepreneurial programs. This support will indirectly encourage changes in students' mindset who will be entrepreneurs. Regardless of the family environment, students create their own business also influenced by the university context (Shirokova et al., 2015). Prospective entrepreneurs with student background spend most of their time in study place, so the academic environment significantly influences their disposition to certain activities.

In several universities that have entrepreneurial programs, of course, they have many initiatives in developing student interest. These initiatives include special programs, for example, technical training and workshops related to entrepreneurship, so they are designed to provide them with the basic knowledge and skills needed to start a business (Shirokova et al., 2016; Klofsten, 2000). The existence of educational initiatives focused on improving the quality of human resources, developing business basics, and compensating for the lack of experience of students as budding entrepreneurs (Zhao et al., 2005). Accelerators in the form of university-based business incubators with student members have the opportunity to receive opportunities to turn their ideas into reality, seek investors, play an important role in changing entrepreneurial intentions, and seek practitioner support into entrepreneurial action (Hughes et al., 2007).

Universities can change into a social capital source for young entrepreneurs, through mentoring programs, seminars, and training events involving expert and experienced entrepreneurs, are designed not only to give knowledge and useful skills but also to expand the business network of the students (Nielsen \& Lassen, 2012; Boh et al., 2016; Hayter, 2016; Burciul \& Kerr, 2018; Shirokova et al., 2018; MacMillan \& Day, 1987; Terjesen et al., 2016; Bruton et al., 2015; Sequeira et al., 2007). The hypothesis in this study is used to answer conjecture while referring to theoretical support and several relevant studies. Based on the above thoughts, it can be proposed the following hypothesis as follows:

$H_{1}$ : Entrepreneurial intentions that have been planned to influence the action of becoming an entrepreneur (entrepreneurial activities).

$\mathrm{H}_{2}$ : Perception desirability encourages an increase in the intention of entrepreneurship.

$\mathrm{H}_{3}$ : Perceived feasibility increases the intention of entrepreneurship.

$H_{4}$ : Students with the background having family business strengthen their intention to become entrepreneurs (entrepreneurial activities).

$H_{5}$ : Indonesian students who come from universities with a good entrepreneurial environment will strengthen their intention to become entrepreneurs (entrepreneurial activities).

\section{METHODOLOGY}

\section{Data and Sample}

Data were collected using the survey technique, which consists of students in several leading universities in Indonesia. Indonesia is a big country. Questionnaires distribution mechanism by using mail survey or electronic survey to students at several universities in Sumatra Island (Syiah Kuala University, University of Riau, University of North Sumatra), Java Island (Bogor Agricultural Institute, University of Indonesia, Gadjah Mada University, Brawijaya University, Diponegoro University), Kalimantan Island (Mulawarman University, Tanjungpura University, Lambung Mangkurat University), Sulawesi Island (Hasanuddin University, Tadulako University, Sam Ratulangi University), Nusa Tenggara Island (Mataram University), Maluku Island (Patimura University) and Papua Island (Cendrawasih University). Sample selection by Instagram account or faculty or university that is published. The reason we chose these campuses as objects of the study was that they had developed students in entrepreneurship, so the environment was very supportive of their practice.

Data collection used an authoritative instrument that aims to gain students' aspirations by considering factors such as family support, university environment to have an entrepreneurial intention and realize their intentions into entrepreneurial activities. From January 2020 to April 2020 there were 983 questionnaires sent by Email, WhatsApp (WA), or Instagram accounts owned by students. From the 983 distributed only 234 questionnaires were returned and only 187 questionnaires were completed and could be used. 


\section{Variable Measurement}

The questions are designed related to perceptions of desires and perceptions of feasibility, which come from strong sources. The questionnaire used refers to Shapero \& Sokol (1982) and studied by Krueger (1993), Cooper et al. (1986), and Krueger (2019). The independent variable perceived desirability is based on three questions: perceived desirability PD (1) how far do you want to have a new company or a new business ?; PD (2) How much is your passion for building this new business ?; and PD (3) How much is your enthusiasm for the plan to open a new business? Each response received by respondents will be assessed on a Likert scale, start from 1 (the lowest score) to seven 7 (the highest score). Use the final value or score by calculating the average for all questions. The variable perceived feasibility method of measurement is the same, using three questions: PF (1) how difficult is it to open and manage a new business ?; PF (2) how much of your belief will be your success ?; PF (3) how much do you believe in yourself?. To simplify the explanation and role of the variables used, we summarize in Figure 1.

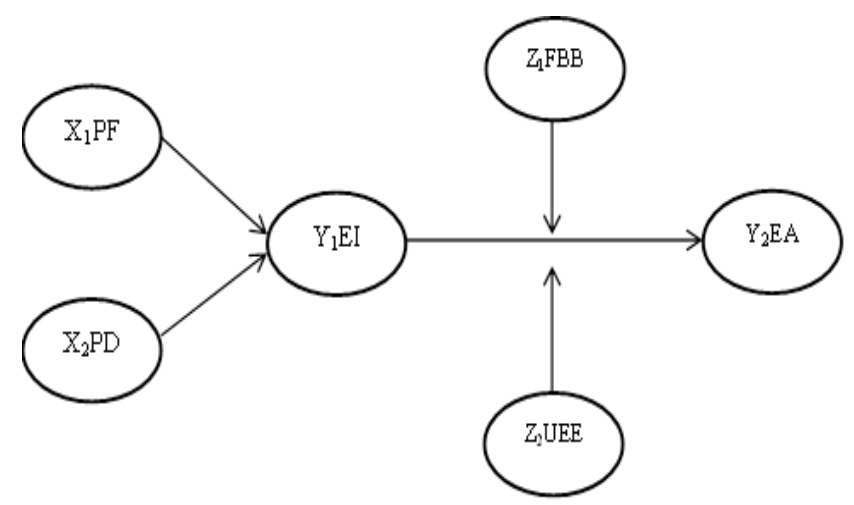

Figure 1: Research model

Explanation: X1 (PF as perceived feasibility), X2 (PD as perceived desirability), Y1 (EI as entrepreneurial intention), Z1 (FBB as family business background), Z2 (UEE as university entrepreneurial environment), Y2 (EA as entrepreneurial activities).

The intention of entrepreneurship of a student is to explore students' perceptions of their "readiness to become entrepreneurs", "entrepreneurs are the main goals of their lives", "steps to become entrepreneurs" and "intentions and desires". Variable the intention of entrepreneurship of a student develops an instrument compiled by Liñan \& Chen (2009). Statements related to entrepreneurial intentions use a scale of 1 (totally disagree) to 7 (fully agree)., " I am willing to do all the things that deserve to be an entrepreneur ", "I have the main goal in life being an entrepreneur", " I will maximize my professional ability to start a new business ", "I have a strong intention to create a new business in the future ", " I am very serious about exploring a new business someday ", and "I intend to seriously start a new business after I finish college". The endogenous variable of action become entrepreneur (entrepreneurial activities) is measured by the type of nominal data, number 1 if you have independent data, otherwise is 0 (Liñan \& Chen, 2009; Bogatyreva \& Shirokova, 2017).

One of the study goals is the presence of moderating variables that moderate the students' intention and their actual involvement in business activities, the moderating variables used were: coming from families that own business (FBB) and university environment (UEE). The family business background variable is measured by nominal data type, number 1 if continuing the family business, others 0 . The university entrepreneurial environment is assessed by students by using scale 1 (totally disagree) to 7 (fully agree) to evaluate the following statement: "The lecture process at my university is very inspiring for me to develop ideas and innovations to start a new business ", " There is a favorable academic climate on campus, to become an entrepreneur", "The students are encouraged to be involved in various entrepreneurial activities that incubate students to become entrepreneurs " (Franke \& Lüthje, 2004).

After the data was collected, we processed it with the help of Statistical Product and Service Solutions (SPSS) version 25. The SPSS program aims to describe the numbers in it with statistical requirements. In addition, hypothesis testing needs to be empirically determined and the regression model becomes the basis for this study.

\section{FINDINGS}

Table 1 reports that the descriptive statistics of the six independent variables varied widely. The highest average value is perceived desirability with a score of 5.45 and the lowest for the variable perceived feasibility is 4.98 . Then, perceived desirability as a variable with the highest standard deviation value is 1.123 and the university entrepreneur environment variable is the lowest at 1.072. As additional information, entrepreneurial intention and entrepreneurial activities intention act as dependent variables, while the family business background and university entrepreneur environment are mediating variables that have an indirect effect. 
Table 1: Descriptive statistics

\begin{tabular}{llll}
\hline No. & Variables & Mean & Standard Deviation \\
\hline 1. & Perceived desirability & 5.45 & 1.123 \\
\hline 2. & Perceived feasibility & 4.98 & 1.094 \\
\hline 3. & Entrepreneurial intention & & \\
\hline 4. & Family business background & & \\
\hline 5. & University entrepreneur environment & 5.67 & 1.072 \\
\hline 6. & Entrepreneurial activities & & \\
\hline
\end{tabular}

Source: Compiled by the author.

The research hypothesis is analyzed using three steps logistic regression. To exclude heteroscedasticity, strong standard errors are used in all three stages of testing. Hypothesis testing results are presented in Table 2. The first stage testing the logistic regression of perceived desirability and perceived feasibility impacts on students' intentions to be entrepreneurial. The analysis showed perceived desirability influence positively and significantly on students' entrepreneurial intentions $(b=0.067, p=0.034)$, while the perceived feasibility did not have significant impact on intentions to be entrepreneurial of students $(b=0.114, p=0.129)$.

Table 2: Regression analysis results

\begin{tabular}{|c|c|c|c|c|}
\hline No. & Variables & Stage I & Stage II & Stage III \\
\hline & \multicolumn{4}{|l|}{ Direct effects } \\
\hline 1. & $\mathrm{PD} \rightarrow \mathrm{EI}$ & $.067^{*}$ & & \\
\hline \multirow[t]{2}{*}{2.} & $\mathrm{PF} \rightarrow \mathrm{EI}$ & $.114^{* * *}$ & & \\
\hline & \multicolumn{4}{|l|}{ Direct effects } \\
\hline \multirow[t]{2}{*}{3.} & $\mathrm{EI} \rightarrow \mathrm{EA}$ & & $.432^{*}$ & \\
\hline & Moderating effect & & & \\
\hline 4. & $\mathrm{FB}^{*} \rightarrow \mathrm{EI} \rightarrow \mathrm{EA}$ & & & $-.075^{* *}$ \\
\hline 5. & $\mathrm{UEE}^{*} \mathrm{EI} \rightarrow \mathrm{EA}$ & & & $.126^{*}$ \\
\hline
\end{tabular}

Explanation: ${ }^{*}$ Sig at $0.05,{ }^{* *}$ Sig at 0.01 .

Source: Compiled by the author.

At the second stage, the main effect of direct relationship between students intention and participation in entrepreneurial activity produced coefficient $(\mathrm{b}=0.432, \mathrm{p}<0.041)$, and direct relationship of moderating variables produced positive effect on family business background coefficient $(b=0.346, p=0.023)$, and there are negative impacts of university entrepreneurial environment with coefficients $(b=-0.128, p=0.013)$. In the third stage, testing the moderating effects. The results of the moderating variable test produced negative moderating effects from a family business background and not significant $(\mathrm{b}=-0.075, \mathrm{p}=0.178)$, as well as university environment produced positive but not significant moderating effect $\left((b=0.126, p=0.213)\right.$, thus this study accepts $\mathrm{H}_{1}$ and $\mathrm{H}_{2}$, but does not support $\mathrm{H}_{3}, \mathrm{H}_{4}$, and $\mathrm{H}_{5}$.

\section{DISCUSSIONS}

The analysis results showed that entrepreneurial intention describes the actions taken to implement it in the future. The results are in line with the planned behavior theory (Ajzen, 1991) which implies a direct relationship between intentions and actions taken to implement them. Our results confirm the theory validity regarding the transition from the entrepreneurial aspirations to starting and running an independent business by students as new entrepreneurs in Indonesia. Entrepreneurial intention usually takes a long time, full consideration, and changes along with input and information received. This conclusion is in line with most relevant researches (Kautonen et al., 2013, 2015; Liñán \& Fayolle, 2015; Shirokova et al., 2015; Bogatyreva \& Shirokova, 2017; Edelman et al., 2016).

The theory of planned behavior that was developed to explain the mechanism of intention formation towards business does not fully explain the gap to action, that is, a situation where the intentions that arise are not actually realized. Our test results show that the transition from the first to the last aspect is influenced by context and factors that can increase or decrease the likelihood of a transition. Students who are considering a career as entrepreneurs and come from families who have businesses, seem unaware of this potential. This finding contradicts the original hypothesis about the role of the family business in this process. There are several possible explanations that people who come from families who have certain businesses can realize entrepreneurial ideals because not only by establishing their own company but also by becoming a successor to the family business. Students who have a business background tend to be children of the have family, possess assets, and tend to be spoiled, so the effort intention is reduced. Other research (Colton, 1981; McClelland, 1965, 1987), explains that adolescent success can be driven by psychological factors. A person can succeed if there is an urge to succeed, not just the parent's ability, or continue the family business.

In previous studies, many considered that adolescent whose parents had business background be considered as a key predictor of business independence (Hsu et al., 2016; Wang et al., 2018; Shirokova et al., 2016; Henley et al., 2017; 
Herman \& Stefanescu, 2017). Children who see how their parents or family manage a business will also easily take an example of managing the business. This experience according to Edelman et al. (2016) is an important matter as a first step in developing a business spirit, but this study has conflicting results. It provides a valuable lesson that entrepreneurs who are just starting a business, can take many strategic steps, which can partially explain the negative correlation between adolescents who come from families that own business and take action to implement entrepreneurial intentions. Another factor that may affect the lower level of Indonesian students who come from families who have businesses realize their entrepreneurial intentions may have doubts about the entrepreneurs' prospects in Indonesia, reinforced by the practical experience of their families.

The test results showed an insignificant influence between university environment that supports entrepreneurship can have an impact on students to become entrepreneurs. Although the university provided various support for entrepreneurship, the overall existing social assets and capital require further development (Barral et al., 2018; $\underline{\text { Smirnov }}$ et al., 2020). However, there are important things that the university has been providing long-term capital in entrepreneurship development for students (Erikson, 2002). The various efforts made by universities, which cover various fields of university activity in the form of academic initiatives, and creation of innovation centers, commercialization of research results, expansion of funding sources, promotion of entrepreneurial culture and good business environment, and active cooperation with business community members (Léon, 2019; Genoveva, 2019; Guerrero \& Urbano, 2012). Such programs are actually trying to change students' mindset from being employee become an independent entrepreneur.

\section{CONCLUSION}

We used the planned behavior theory in an effort to test the intentions and desires of student entrepreneurship which are moderated by two factors, namely family background that has independent business and university program support. The research results showed that both driving variables did not produce moderating effects, which means that they did not push entrepreneurial intention to become a reality. However, in order to encourage intentions, it turns out that the perceived desirability is very dominant, encouraging the students' intention to become entrepreneurs. Strong desire from an individual becomes a strength and encourages enthusiasm, encouraging enthusiasm to become an independent entrepreneur.

Several previous studies have supported our findings. They have revealed that perceived desirability and perceived feasibility have a significant effect on student entrepreneurial intention on campus (Israr \& Saleem, 2018; Li et al., 2020; Y1ldirim et al., 2016; Sharma, 2014).

\section{LIMITATION AND STUDY FORWARD}

Our research has a limitation, such as cross-sectional data are used in the form of intention power and entrepreneurial action is taken to create new business measured only at one point of time, do not give an opportunity to assess the change dynamics in the future. Because intentions tend to change, the explanatory function that appears usually decreases with time (Sutton, 1998). Therefore, the role of various factors that influence the intention-action transition is the main research focus. However, possible areas for studying the relationship between intentions and entrepreneurial activities in the Indonesian context can be found in a study done in several stages (longitudinal study). In this research, we used students as a sample, did not try samples outside of students that also young that more focused on establishing independent businesses. For researches in the future, able to examine factors that influence the entrepreneurial intention transition from different social groups. Also, our analysis results are only relevant to the Indonesian context.

\section{ACKNOWLEDGEMENT}

We need to thank those who directly helped so that this study can be carried out. The cooperation that involves the Faculty of Economics, University of Mulawarman, and Sekolah Tinggi Ilmu Ekonomi Samarinda is going well. Specific support has provided us with financial support from both institutions.

\section{AUTHORS CONTRIBUTION}

We declare there are no conflicts of interest that may cause problems in the future. This study is aimed at academics and the public. The authors have worked together in drafting the script. Dr. Irwansyah has a role as the development of concepts and assumptions (20\%), Dr. Ardi Paminto has a share in the method specification (35\%), Dr. Yana Ulfah for carrying the research (10\%), Muhammad Ikbal performed the analysis of the results, and conclusions formulation (25\%), and Dio Caisar Darma for the remaining contribution (10\%).

\section{REFERENCES}

1. Abbasianchavari, A., \& Moritz, A. The impact of role models on entrepreneurial intentions and behavior: a review of the literature. Management Review Quarterly, 2020, 1-14. https://doi.org/10.1007/s11301-019-001790

2. Ajzen, I. (1991). The theory of planned behavior. Organizational Behavior and Human Decision Processes, 50(2), 179-211. https://doi.org/10.1016/0749-5978(91)90020-T 
3. Ajzen, I. (2005). Attitudes, Personality, and Behavior. McGraw-Hill Education. https://psicoexperimental.files.wordpress.com/2011/03/ajzeni-2005-attitudes-personality-and-behaviour-2nded-open-university-press.pdf

4. Ajzen, I., Czasch C., \& Flood M. G. (2009). From Intentions to Behavior: Implementation Intention, Commitment, and Conscientiousness. Journal of Applied Social Psychology, 39(6), 1356-1372. https://doi.org/10.1111/j.1559-1816.2009.00485.x

5. Armitage, C .J., \& Conner, M. (2001). Efficacy of the Theory of Planned Behavior: A meta-analytic review. British Journal of Social Psychology, 40(4), 471-499. https://doi.org/10.1348/014466601164939

6. BPS-Statistics of Indonesia. (2017). Indonesian Statistics 2017. Dharmaputra. https://www.bps.go.id/publication/2017/07/26/b598fa587f5112432533a656/statistik-indonesia-2017.html

7. Barral, M. R., Ribeiro, F. G., \& Canever, M. D. (2018). Influence of the university environment in the entrepreneurial intention in public and private universities. RAUSP Management Journal, 53(1), 122-133. https://doi.org/10.1016/j.rauspm.2017.12.009

8. Baluku, M. M., Kikooma, J. F., \& Kibanja, G. M. (2016). Psychological capital and the startup capitalentrepreneurial success relationship. Journal of Small Business \& Entrepreneurship, 28(1), 27-54. https://doi.org/10.1080/08276331.2015.1132512

9. Bird, B., \& Jelinek, M. (1988). The Operation of Entrepreneurial Intentions. Entrepreneurship Theory and Practice, 13(2), 21-29. https://doi.org/10.1177/104225878801300205

10. Bogatyreva, K., \& Shirokova, G. (2017). From Entrepreneurial Aspirations to Founding a Business: The Case of Russian Students. Foresight and STI Governance, 11(3), 25-36. https://doi.org/10.17323/25002597.2017.3.25.36

11. Boh, W. F., De-Haan, U., \& Strom, R. (2016). University Technology Transfer Through Entrepreneurship: Faculty and Students in Spinoffs. The Journal of Technology Transfer, 41(4), 661-669. https://doi.org/10.1007/s10961-015-9399-6

12. Boyd, N. G., \& Vozikis, G. S. (1994). The Influence of Self-Efficacy on the Development of Entrepreneurial Intentions and Actions. Entrepreneurship Theory and Practice, 18(4), 63-77. https://doi.org/10.1177/104225879401800404

13. Bruton, G., Khavul, S., Siegel, D., \& Wright, M. (2015). New Financial Alternatives in Seeding Entrepreneurship: Microfinance, Crowdfunding, and Peer-to-Peer Innovations. Entrepreneurship Theory and Practice, 39(1), 9-26. https://doi.org/10.1111/etap.12143

14. Burciul, B., \& Kerr, K. (2018). Case Study: Education in Support of Social Transformation-The Mastercard Foundation Scholars Program. Palgrave Macmillan, Cham. https://doi.org/10.1007/978-3-319-62734-2_16

15. Busenitz, L., \& Lau, C. (1996). A Cross-Cultural Cognitive Model of New Venture Creation. Entrepreneurship Theory and Practice, 20(4), 25-40. https://doi.org/10.1177/104225879602000403

16. Busenitz, L. W., \& Barney, J. B. (1997). Differences between entrepreneurs and managers in large organizations: Biases and heuristics in strategic decision-making. Journal of Business Venturing, 12(1), 9-30. https://doi.org/10.1016/S0883-9026(96)00003-1

17. Byabashaija, W., \& Katono, I. (2011). The impact of college entrepreneurial education on entrepreneurial attitudes and intention to start a business in Uganda. Journal of Developmental Entrepreneurship, 16(01), 127 144. https://doi.org/10.1142/S1084946711001768

18. Chlosta, S., Patzelt, H., Klein, S. B., \& Dormann, C. (2012). Parental role models and the decision to become self-employed: The moderating effect of personality. Small Business Economics, 38(1), 121-138. https://doi.org/10.1007/s11187-010-9270-y

19. Colton, R. M. (1981). National science foundation experience with university-industry centers for scientific research and technological innovation (an analysis of issues, characteristics and criteria for their establishment). Technovation, 1(2), 97-108. https://doi.org/10.1016/0166-4972(81)90012-2

20. Contreras, F., de Dreu, I., \& Espinosa, J. C. (2017). Examining the Relationship between Psychological Capital and Entrepreneurial Intention: An Exploratory Study. Asian Social Science, 13(3), 80-88. https://doi.org/10.5539/ass.v13n3p80

21. Cooper, A. C., Willard, G. E., \& Woo, C. Y. (1986). Strategies of high-performing new and small firm: A reexamination of the niche concept. Journal of Business Venturing, 1(3), 247-260. https://doi.org/10.1016/0883-9026(86)90003-0

22. Denanyoh, R., Adjei, K., \& Nyemekye, G. E. (2015). Factors That Impact on Entrepreneurial Intention of Tertiary Students in Ghana. International Journal of Business and Social Research, 5(3), 19-29. http://dx.doi.org/10.18533/ijbsr.v5i3.693

23. Drucker, P. (2014). Innovation and Entrepreneurship ( ${ }^{\text {st }}$ Edition). Routledge. https://books.google.co.id/books/about/Innovation and_Entrepreneurship.html?id=OiuDBAAAQBAJ\&redir es $\mathrm{c}=\mathrm{y}$

24. Dunn, T., \& Holtz-Eakin, D. (2000). Financial capital, human capital, and the transition to self-employment: Evidence from intergenerational links. Journal of Labor Economics, 18(2), 282-305. http://dx.doi.org/10.1086/209959 
25. Ebewo, P. E., Rugimbana, R., \& Shambare, R. (2017). Effects of Entrepreneurship Education on Students' Entrepreneurial Intentions: A Case of Botswana. Management Studies, 5(4), 278-289. http://dx.doi.org/10.17265/2328-2185/2017.04.002

26. Edelman, L. F., Manolova, T., Shirokova, G., \& Tsukanova, T. (2016). The impact of family support on young entrepreneurs' start-up activities. Journal of Business Venturing, 31(4), 428-448. https://doi.org/10.1016/j.jbusvent.2016.04.003

27. Edoho, F. M. (2016). Entrepreneurship paradigm in the new millennium: A critique of public policy on entrepreneurship. Journal of Entrepreneurship in Emerging Economies, 8(2), 279-294. https://doi.org/10.1108/JEEE-08-2015-0043

28. Erikson, T. (2002). Entrepreneurial capital: the emerging venture's most important asset and competitive advantage. Journal of Business Venturing, 17(3), 275-290. https://doi.org/10.1016/S0883-9026(00)00062-8

29. Fayolle, A., \& Gailly, B. (2015). The impact of entrepreneurship education on entrepreneurial attitudes and intention: Hysteresis and persistence. Journal of Small Business Management, 53(1), 75-93. https://doi.org/10.1111/jsbm.12065

30. Franke, N., \& Lüthje, C. (2004). Entrepreneurial Intentions of Business Students: A Benchmarking Study. International Journal of Innovation and Technology Management, 1(3), 269-288. http://dx.doi.org/10.1142/S0219877004000209

31. Fuller, B., Liu, Y., Bajaba, S., Marler, L. E., \& Pratt, J. (2018). Examining how the personality, self-efficacy, and anticipatory cognitions of potential entrepreneurs shape their entrepreneurial intentions. Personality and Individual Differences, 125, 120-125. https://doi.org/10.1016/j.paid.2018.01.005

32. Genoveva, G. (2019). The influence of entrepreneurial culture on entrepreneurial intention among business students. Firm Journal of Management Studies, 4(1), 40-56. https://doi.org/10.33021/firm.v4i1.682

33. Guerrero, M., \& Urbano, D. (2012). The development of an entrepreneurial university. The Journal of Technology Transfer, 37, 43-74. https://doi.org/10.1007/s10961-010-9171-X

34. Hayter, C. S. (2016). A trajectory of early-stage spinoff success: the role of knowledge intermediaries within an entrepreneurial university ecosystem. Small Business Economics, 47(3), 633-656. https://doi.org/10.1007/s11187-016-9756-3

35. Henley, A., Contreras, F., Espinosa, J. C., \& Barbosa, D. (2017). Entrepreneurial intentions of Colombian business students: Planned behaviour, leadership skills and social capital. International Journal of Entrepreneurial Behavior \& Research, 23(6), 1017-1032. https://doi.org/10.1108/IJEBR-01-2017-0031

36. Herman, E., \& Stefanescu, D. (2017). Can higher education stimulate entrepreneurial intentions among engineering and business students?. Educational Studies, 43(3), 312-327. https://doi.org/10.1080/03055698.2016.1277134

37. Heuer, A., \& Liñán, F. (2013). Testing Alternative Measures of Subjective Norms in Entrepreneurial Intention Models. International Journal of Entrepreneurship and Small Business, 19(1), 35-50. https://doi.org/10.1504/IJESB.2013.054310

38. Hsu, D. K., Wiklund, J., Anderson, S. E., \& Coffey, B. S. (2016). Entrepreneurial exit intentions and the business-family interface. Journal of Business Venturing, 31(6), 613-627. https://doi.org/10.1016/i.jbusvent.2016.08.001

39. Hughes, M., Ireland, R. D., \& Morgan, R. E. (2007). Stimulating Dynamic Value: Social Capital and Business Incubation as a Pathway to Competitive Success. Long Range Planning, 40(2), 154-177. https://doi.org/10.1016/j.1rp.2007.03.008

40. Indriastuti, H., Kasuma, J., Zainurrosalamia, S., Darma, D. C., \& Sawangchai, A. (2020). Achieving Marketing Performance through Acculturative Product Advantages: The Case of Sarong Samarinda. Asian Journal of Business and Accounting, 13(1), 241-261. https://doi.org/10.22452/ajba.vol13no1.9

41. Israr, M., \& Saleem, M. (2018). Entrepreneurial intentions among university students in Italy. Journal of Global Entrepreneurship Research, 8(1), 1-14. https://doi.org/10.1186/s40497-018-0107-5

42. Karimi, S., Biemans, H. J., Lans, T., Chizari, M., \& Mulder, M. (2016). The impact of entrepreneurship education: A study of Iranian students' entrepreneurial intentions and opportunity identification. Journal of Small Business Management, 54(1), 187-209. https://doi.org/10.1111/jsbm.12137

43. Kautonen, T., Van Gelderen, M., \& Tornikoski, E. T. (2013). Predicting entrepreneurial behaviour: a test of the theory of planned behaviour. Applied Economics, 45(6), 697-707. https://doi.org/10.1080/00036846.2011.610750

44. Kautonen, T., van Gelderen, M., \& Fink, M. (2015). Robustness of the Theory of Planned Behavior in Predicting Entrepreneurial Intentions and Actions. Entrepreneurship Theory and Practice, 39(3), 655-674. https://doi.org/10.1111/etap.12056

45. Klofsten, M. (2000). Training Entrepreneurship at Universities: A Swedish Case. Journal of European Industrial Training, 24(6), 337-344. https://doi.org/10.1108/03090590010373325

46. Krueger, N. (1993). The impact of prior entrepreneurial exposure on perceptions of new venture feasibility and desirability. Entrepreneurship Theory and Practice, 18(1), 5-21. https://doi.org/10.1177/104225879301800101

47. Krueger, N. (2009). Entrepreneurial Intentions are Dead: Long Live Entrepreneurial Intentions. Understanding the Entrepreneurial Mind, 24, 51-72. https://doi.org/10.1007/978-1-4419-0443-0_4 
48. Kunkel, S. W. (1991). The impact of strategy and industry structure on new venture performance. The University

https://books.google.co.id/books/about/The_Impact_of_Strategy and_Industry_Stru.html?id=WBubwwEACA

AJ\&redir esc $=$ y

49. Lentz, B. F., \& Laband, D. N. (1990). Entrepreneurial Success and Occupational Inheritance among Proprietors. The Canadian Journal of Economics, 23(3), 563-579. https://doi.org/10.2307/135648

50. Léon, F. (2019). Long-term finance and entrepreneurship. Economic Systems, 43(2), 100690. https://doi.org/10.1016/j.ecosys.2018.10.004

51. Liñán, F., \& Fayolle, A. (2015). A systematic literature review on entrepreneurial intentions: citation, thematic analyses, and research agenda. International Entrepreneurship and Management Journal, 11(4), 907-933. https://doi.org/10.1007/s11365-015-0356-5

52. Li, C., Ahmed, N., Qalati, S. A., Khan, A., \& Naz, S. (2020). Role of Business Incubators as a Tool for Entrepreneurship Development: The Mediating and Moderating Role of Business Start-Up and Government Regulations. Sustainability, 12(5), 1-23. https://doi.org/10.3390/su12051822

53. Low, M. B., \& MacMillan, I. C. (1988). Entrepreneurship: Past research and future challenges. Journal of Management, 14(2), 139-161. https://doi.org/10.1177/014920638801400202

54. MacMillan, I. C., \& Day, D. (1987). Corporate ventures into industrial markets: Dynamics of aggressive entry. Journal of Business Venturing, 2(1), 29-39. https://doi.org/10.1016/0883-9026(87)90017-6

55. McClelland, D. C. (1965). N achievement and entrepreneurship: A longitudinal study. Journal of Personality and Social Psychology, 1(4), 389-392. https://doi.org/10.1037/h0021956

56. McClelland, D. C. (1987). Characteristics of Successful Entrepreneurs*. The Journal of Creative Behavior, 21(3), 219-233. https://doi.org/10.1002/j.2162-6057.1987.tb00479.x

57. McClelland, D. C. (1987). Human Motivation. Cambridge University Press. https://doi.org/10.1017/CBO9781139878289

58. McDougall, P. P. (1989). International versus domestic entrepreneurship: New venture strategic behavior and industry structure. Journal of Business Venturing, 4(6), 387-400. https://doi.org/10.1016/0883-9026(89)90009$\underline{8}$

59. Mitchell, R. K., Busenitz, L., Lant, T., McDougall, P. P., Morse, E. A., \& Smith, J. B. (2002). Toward a theory of entrepreneurial cognition: Rethinking the people side of entrepreneurship research. Entrepreneurship Theory and Practice, 27(2), 93-104. https://doi.org/10.1111/1540-8520.00001

60. Mueller, P. (2006). Exploring the knowledge filter: How entrepreneurship and university-industry relationships drive economic growth. Research Policy, 35(10), 1499-1508. https://doi.org/10.1016/j.respol.2006.09.023

61. Muliadi, M., Darma, D. C., \& Kasuma, J. (2020). MSMEs as Mediation in the Effects of Investment Credit, Interest Rates, and Labor on Economic Growth: Evidence from Indonesia. International Journal of Finance \& Banking Studies, 9(2), 01-12. https://doi.org/10.20525/ijfbs.v9i2.702

62. Nielsen, S. L., \& Lassen, A. H. (2012). Images of entrepreneurship: towards a new categorization of entrepreneurship. International Entrepreneurship and Management Journal, 8(1), 35-53. https://doi.org/10.1007/s11365-010-0159-7

63. Nowak, H. (2016). The Role of the Polish Higher Education System in the Development of Entrepreneurship. Entrepreneurial Business and Economics Review, 4(1), 43-59. https://doi.org/10.15678/EBER.2016.040104

64. Orbell, S., \& Sheeran, P. (1998). 'Inclined abstainers': A problem for predicting health-related behaviour. British Journal of Social Psychology, 37(2), 151-165. https://doi.org/10.1111/j.2044-8309.1998.tb01162.x

65. Piperopoulos, P., \& Dimov, D. (2015). Burst bubbles or build steam? Entrepreneurship education, entrepreneurial self-efficacy, and entrepreneurial intentions. Journal of Small Business Management, 53(4), 970-985. https://doi.org/10.1111/jsbm.12116

66. Popescu, C., Bostan, I., Robu, I. B., \& Maxim, A. (2016). An Analysis of the Determinants of Entrepreneurial Intentions among Students: A Romanian Case Study. Sustainability, 8(8), 771-793. https://doi.org/10.3390/su8080771

67. Premand, P., Brodmann, S., Almeida, R., Grun, R., \& Barouni, M. (2016). Entrepreneurship Education and Entry into Self-Employment Among University Graduates. World Development, 77, 311-327. https://doi.org/10.1016/j.worlddev.2015.08.028

68. Rauch, A., van Doorn, R., \& Hulsink, W. (2014). A Qualitative Approach to Evidence-Based Entrepreneurship: Theoretical Considerations and an Example Involving Business Clusters. Entrepreneurship Theory and Practice, 38(2), 333-368. https://doi.org/10.1111/etap.12093

69. Rokhman, W., \& Ahamed, F. (2015). The role of social and psychological factors on entrepreneurial intention among Islamic college students in Indonesia. Entrepreneurial Business and Economics Review, 3(1), 29-42. https://doi.org/10.15678/EBER.2015.030103

70. Rumelt, R. P. (2005). Theory, Strategy, and Entrepreneurship. Handbook Series on Entrepreneurship, 2, 11-32. https://doi.org/10.1007/0-387-23622-8_2

71. Saeed, S., Yousafzai, S. Y., Yani-De-Soriano, M., \& Muffatto, M. (2015). The role of perceived university support in the formation of students' entrepreneurial intention. Journal of Small Business Management, 53(4), 1127-1145. https://doi.org/10.1111/jsbm.12090 
72. Sandberg, W. R., \& Hofer, C. W. (1987). Improving new venture performance: The role of strategy, industry structure, and the entrepreneur. Journal of Business Venturing, 2(1), 5-28. https://doi.org/10.1016/08839026(87)90016-4

73. Shchegolev, A. V., Ovechkin, M. V., \& Sherstobitova, V. N. (2018)> Automated Calculation of Bulk-Stamping Matrices for Circular Blanks. Russian Engineering Research, 38(5), 411-414. https://doi.org/10.3103/S1068798X18050179

74. Sequeira, J., Mueller, S. L., \& McGee, J. E. (2007). The influence of social ties and self-efficacy in forming entrepreneurial intentions and motivating nascent behavior. Journal of Developmental Entrepreneurship, 12(3), 275-293. https://doi.org/10.1142/S108494670700068X

75. Shane, S., \& Venkataraman, S. (2000). The promise of entrepreneurship as a field of research. Academy of Management Review, 25(1), 217-226. https://doi.org/10.2307/259271

76. Shapero, A., Sokol, L. (1982). The Social Dimensions of Entrepreneurship. University of Illinois at UrbanaChampaign's Academy for Entrepreneurial Leadership Historical Research Reference in Entrepreneurship. https://ssrn.com/abstract $=1497759$

77. Sharma, L. (2014). Impact of family capital \& social capital on youth entrepreneurship - a study of Uttarakhand state, India. Journal of Global Entrepreneurship Research, 4, 14. https://doi.org/10.1186/s40497-014-0014-3

78. Shirokova, G., Tsukanova, T., \& Bogatyreva, K. (2015). University Environment and Student Entrepreneurship: The Role of Business Experience and Entrepreneurial Self-Efficacy. Educational Studies, Higher School of Economics, 3, 171-207. https://doi.org/10.17323/1814-9545-2015-3-171-207

79. Shirokova, G., Osiyevskyy, O., \& Bogatyreva, K. (2016). Exploring the intention-behavior link in student entrepreneurship: Moderating effects of individual and environmental characteristics. European Management Journal, 34(4), 386-399. https://doi.org/10.1016/j.emj.2015.12.007

80. Shirokova, G., Tsukanova, T., \& Morris, M. H. (2018). The moderating role of national culture in the relationship between university entrepreneurship offerings and student start-up activity: an embeddedness perspective. Journal of Small Business Management, 56(1), 103-130. https://doi.org/10.1111/jsbm.12363

81. Slavtchev, V., Laspita, S., \& Patzelt, H. (2012). Effects of entrepreneurship education at universities. Jena Economic Research Papers, 2012(025), 1-33. https://www.researchgate.net/publication/239808063_Effects_of entrepreneurship_education_at universities

82. Smirnov, V. V., Zakharova, A. N., Abramova, A. G., Dulina, G. S., \& Semenov, V. L. (2020). Development of Youth Entrepreneurship in the Russian Region. Advances in Economics, Business and Management Research, 139, 108-114. https://doi.org/10.2991/aebmr.k.200509.021

83. Sutton, S. (1998). Predicting and Explaining Intentions and Behavior: How Well are We Doing?. Journal of Applied Social Psychology, 28(15), 1317-1338. https://doi.org/10.1111/j.1559-1816.1998.tb01679.x

84. Terjesen, S., Bosma, N., \& Stam, E. (2016). Advancing public policy for high-growth, female, and social entrepreneurs. Public Administration Review, 76(2), 230-239. https://doi.org/10.1111/puar.12472

85. Testa, S., \& Frascheri, S. (2015). Learning by failing: What we can learn from un-successful entrepreneurship education. The International Journal of Management Education, 13(1), 11-22. https://doi.org/10.1016/j.ijme.2014.11.001

86. Tipu, S. A., \& Ryan, J. C. (2016). Predicting entrepreneurial intentions from work values: implications for stimulating entrepreneurship in UAE national youth. Management Decision, 54(3), 610-629. https://doi.org/10.1108/MD-09-2015-0387

87. Toma, S. G., Grigore, A. M., \& Marinescu, P. (2014). Economic Development and Entrepreneurship. Procedia Economics and Finance, 8, 436-443. https://doi.org/10.1016/S2212-5671(14)00111-7

88. van Gelderen, M., Kautonen, T., \& Fink, M. (2015). From entrepreneurial intentions to actions: Self-control and action-related doubt, fear, and aversion. Journal of Business Venturing, 30(5), 655-673. https://doi.org/10.1016/j.jbusvent.2015.01.003

89. Wahyuningsih, D., Sriwardani, S., Kasuma, J., Nuraliati, N. R., \& Darma, D. C. (2020). Application of Market Innovation Strategies for Banjaran Coffee Products using the Walk Shop. International Journal of Entrepreneurial Research, 3(2), 49-53. https://doi.org/10.31580/ijer.v3i2.1463

90. Wang, D., Wang, L., \& Chen, L. (2018). Unlocking the influence of family business exposure on entrepreneurial intentions. International Entrepreneurship and Management Journal, 14(4), 951-974. https://doi.org/10.1007/s11365-017-0475-2

91. Welter, F., \& Smallbone, D. (2011). Conceptualising entrepreneurship in a transition context. International Journal of Entrepreneurship and Small Business, 3(2), 165-184. https://doi.org/10.1504/IJESB.2006.008928

92. Welter, F., \& Xheneti, M. (2013). Reenacting Contextual Boundaries - Entrepreneurial Resourcefulness in Challenging Environments. Entrepreneurial Resourcefulness: Competing With Constraints. Advances in Entrepreneurship, Firm Emergence and Growth, 15, 149-183. https://doi.org/10.1108/S10747540(2013)0000015009

93. Westhead, P., \& Solesvik, M. Z. (2016). Entrepreneurship education and entrepreneurial intention: do female students benefit?. International Small Business Journal, 34(8), 979-1003. https://doi.org/10.1177/0266242615612534 
94. Yıldırım, N., Çakır, Ö., \& Aşkun, O. B. (2016). Ready to Dare? A Case Study on the Entrepreneurial Intentions of Business and Engineering Students in Turkey. Procedia - Social and Behavioral Sciences, 229, 277-288. https://doi.org/10.1016/j.sbspro.2016.07.138

95. Zapkau, F. B., Schwens, C., Steinmetz, H., \& Kabst, R. (2015). Disentangling the effect of prior entrepreneurial exposure on entrepreneurial intention. Journal of Business Research, 68(3), 639-653. https://doi.org/10.1016/j.jbusres.2014.08.007

96. Zhao, H., Seibert, S., \& Hills, G. (2005). The Mediating Role of Self-Efficacy in the Development of Entrepreneurial Intentions. Journal of Applied Psychology, 90(6), 1265-1272. https://doi.org/10.1037/0021$\underline{9010.90 .6 .1265}$ 